\title{
SLC16A8 Gene
}

National Cancer Institute

\section{Source}

National Cancer Institute. SLC16A8 Gene. NCI Thesaurus. Code C134625.

This gene plays a role in lactate transport in the retina. 